\title{
Productivity, Profitability and Yield Gap Analysis of Wheat (Triticum aestivum L.) under Irrigated Conditions of Rajasthan
}

\author{
R. K. Shivran ${ }^{1}$, Naval Kishor ${ }^{1}$, Ummed Singh ${ }^{2 *}$, B. S. Kherawat ${ }^{1}$, \\ Keshav Mehra ${ }^{1}$ and Richa Pant ${ }^{1}$
}

${ }^{1}$ Krishi Vigyan Kendra, Bikaner-II, Swami Keshwanand Rajasthan Agriculture University, Bikaner-334 303, Rajasthan, India

${ }^{2}$ Agriculture University, Jodhpur-342304, Rajasthan, India

*Corresponding author

\begin{abstract}
A B S T R A C T
Present investigation was conducted by Krishi Vigyan Kendra, Bikaner-II, in four blocks of Bikaner district (Lunkaransar, Chhatargarh, Khajuwala and Pugal) of Rajasthan with the specific objectives to analyze yield gap, economics and extent of farmers' satisfaction and constraints faced by the farmers' in growing of wheat. In this study, 232 respondents selected were the beneficiary farmers' conducted front line demonstrated (FLD) at their fields during 2013-14 to 2018-19. The plot size was 0.4ha for both demonstration and farmers' practice (=Local check). Before conducting FLD, the respondents were made abreast with the latest recommended package of practices of wheat. The demonstrated technologies under FLD resulted in an increase in wheat yield by 17.21 percent over Local Check. The experimental results envisage, technology gap (TG), extension gap (EG) and technology index (TI) to the tune of $2124 \mathrm{~kg} / \mathrm{ha}, 589 \mathrm{~kg} / \mathrm{ha}$ and 34.49 percent respectively. The economic performance of wheat under FLD fetched an additional return of ₹ 7,686/ha and ₹ 2.30/rupee invested. Further, on an average, demonstration plots recorded net return to the tune of ₹ 37,243 ; with the $\mathrm{B}: \mathrm{C}$ ratio of 2.30 over the years. However, under farmers' practice the net return was fetched ₹ $29,557 /$ ha with the B: C ratio of 2.11 . Moreover, respondent satisfaction index (RSI) revealed that 49.52 per centrespondent farmers' expressed high, 34.28 per cent respondent farmers' expressed medium and only 16.19 per cent respondent farmers' expressed low level of satisfaction. High temperature at maturity of wheat in relation to climate change was found to be most confronting constraint as perceived by them and ranked I which was followed by lack of high yielding varieties (II) and frost management and ranked as $\mathrm{X}$ in their priority list. The yield of demonstration was found higher than the local check but still lagging behind its potential yield. Thus, the yield could further be increased through effective extension methods like training and demonstration.
\end{abstract}

\section{Introduction}

Wheat (Triticum aestivum L.) is the second most important cereal crop in India after rice and it is contributing substantially to the national food security by providing more than $50 \%$ of the calories to the peoples. India is second largest producer of wheat in the world 
after China with $12.77 \%$ share in total world wheat production. The total area under the crop is about 29.58 million hectares in the country with a production of 99.70 million tonnes in 2017-18. India's share in wheat acreage is about 15.25 per cent of the world wheat area. The productivity of wheat which was $2988 \mathrm{~kg} /$ hectare in 2010-11 has increased to $3371 \mathrm{~kg} /$ hectare in $2017-18$. The three largest wheat producing states are Uttar Pradesh, Punjab and Madhya Pradesh, which produces 31.88 , 17.85and15.91 million tonnes with a share of 31.98, 17.90and15.96 per cent respectively (Anonymous, 2019). In Rajasthan, wheat is cultivated in 2.81 million hectares area with production of 9.19 million tonnes and productivity of $3270 \mathrm{~kg} / \mathrm{ha}$. This accounts for $9.22 \%$ of total wheat production in India (Anonymous, 2018).

Frontline demonstration is one of the most important and powerful tools for transfer of technology by the perception that 'learning by doing' and 'Seeingis believing'. Frontline demonstration is the new concept of field demonstration evolved by the Indian Council of Agriculture Research (ICAR) with main objective to demonstrate newly released crop production and protection technologies and its management practices at the farmers' fields invary in gagro-climatic regions of the country. The field demonstrations are conducted under the close supervision of scientists of the National Agriculture Research System and are termed as front line demonstrations (Singh et al., 2019). The main objective of front line demonstrations is to demonstrate newly released varieties, improved crop production and protection technologies and its management practices at farmers' field under different agro-climatic regions and farming situations. While demonstrating the technologies at farmers' field, the scientists are required to study the factors contributing higher crop production, field constraints of production and thereby generate production data and feedback information. Realizing the importance of FLDs in transfer of latest technologies, Krishi Vigyan Kendra, Bikaner-II have regularly been conducting FLDs on wheat at farmers' field in four blocks of Bikaner district (Lunkaransar, Chhatargarh, Khajuwala and Pugal) of Rajasthan with the objective of convincing farmers' and extension functionaries together about the production potentialities of production technologies for further wide scale diffusion. Keeping in view of an effective extension approach of FLDs ford is semination of wheat technology, it was felt necessarily that the impact of FLDs conducted by KVK, Bikaner-II needs to be assessed.

In the study region, the productivity of wheat is much lower as compared to average state productivity. The basic and prime reasons for lower productivity in the region identified are viz; cultivation of the crop under rainfed conditions, poor knowledge of drought tolerant improved varieties, and poor adoption of production practices. Further, low productivity in the region has also been ascribed to improper management of irrigation water to the crop, especially at critical stages of growth for the proper growth and development (Joshi et al., 2007). Moreover, in the recent past it has also been noticed that owing to late harvesting of preceding kharif crops, more than 50\% sowing of wheat gets delayed till December or early January. The delayed sowing leads to substantial loss in grain yield, due to unavailability of sufficient irrigation water at the later stages. Furthermore, poor agronomic practices such as seed rate, selection of suitable varieties, nutrient management, weed management and irrigation management etc. are also responsible for low productivity of wheat in India (Tiwari et al., 2014). It is evident from the findings, that there is no scope for area expansion, hence additional 
production has to added to the national food basket by increasing the per hectare productivity (Nagarajan, 1997). Keeping these in view, FLDs of improved production technology on wheat were conducted to enhance the productivity, economic returns and convincing the farmers for adoption of improved production technologies.

\section{Materials and Methods}

Frontline demonstrations on wheat were conducted by several institutes ororganizations in Rajasthan but due to paucity of time and proximity, study was confined to FLDs conducted by KVK Bikaner-II in Bikaner district of Rajasthan. The data on output were collected from FLDs plots and finally the grain yield, cost of cultivation, net returns with the benefit cost ratio was worked out. For the purpose of investigation, five villages from each selected block (Lunkaransar, Chhatargarh, Khajuwala and Pugal) of Bikaner district where FLDs on wheat were conducted during preceding six years (Rabi 2013-14 to 2018-19) were selected. A comprehensive list of FLD farmers' was prepared. Out of this, five beneficiaries from each selected village were randomly selected. Through FLDs, total sample of 105 respondents was undertaken for the study. The Adoption level of the farmers' about improved production practices of wheat before conducting and after conducting FLD was measured. Further, the satisfaction level of respondent farmers' about extension services provided was also measured based on various dimensions like training of participating farmers', timeliness of services, supply of inputs, solving field problems and advisory services, fairness of scientists', performance of variety demonstrated and overall impact of FLDs. The data were collected through personal contacts with the help of well-structured interview schedule. The collected data were processed, tabulated, classified and analyzed interms of mean percent score and ranks etc. A total of 232 frontline demonstrations (FLDs) were laid out at farmers' field to demonstrate the effect of high yielding rainfed varieties, supplemental irrigation (crown root initiation stage $(\mathrm{CRI})$ and CRI + flowering stage) and sowing with seed drill on the productivity of wheat. Each demonstration was laid out on an area of 0.4 ha. Additionally, adjacent plot of 0.4 ha was allocated for the farmers' practice. Before conducting FLDs, lists of farmers' were prepared through group meetings and specific skill trainings given to the selected farmers' regarding package of practices of wheat. To popularize the improved wheat production practices, constraints in wheat production were identified though participatory approach (Table1). Preferential ranking technique was utilized to identify the constraints faced by the respondent farmers' in wheat production. Farmers' were also asked to rank the constraints' they perceived as limiting factor for wheat cultivation in order of preference. Based on top rank farmer's problems identified, front line demonstrations were planned and conducted at the farmers' fields. The improved technologies selected for FLDs were improved high yielding rainfed varieties, supplemental irrigation and sowing with seed drill. The other management practices like, seed treatment, recommended fertilizers dose and plant protection etc. were applied for improved as well as farmers' practice. The crop of wheat was sown at the spacing of 22.5 $\mathrm{cm}$ (row-row) during last week of October to second week of November during all the three years of experimentation. The seed rate was kept $100 \mathrm{~kg} / \mathrm{ha}$. The data for grain yield production and economic was recorded, compared with farmers' practice and analyzed. The extension gap, technology gap and technology index were calculated using the formula as suggested by Samui et al., (2000). 
Extension gap $(\mathrm{kg} / \mathrm{ha})=$ Demonstration yield (kg/ha) - Yield of farmers' practice ( $\mathrm{kg} / \mathrm{ha})$

Technology gap $(\mathrm{kg} / \mathrm{ha})=$ Potential yield (kg/ha) - Demonstration yield (kg/ha).

Technology index $(\%)=\{($ Potential yield Demonstration yield $) \div$ Potential yield $\} \times 100$

The respondents were interviewed personally with the help of a pre-tested and wellstructured interview schedule. Client Satisfaction Index was calculated as developed by Kumaran and Vijayaragavan (2005). The individual obtained scores were calculated using the formulae as:

Client Satisfaction Index $=($ Score obtained by individual $\div$ Maximum score possible)

Knowledge level of the farmers about improved production practices of wheat before and after frontline demonstration implementation was measured and compared by applying paired t-test at 5 per cent level of significance.

\section{Results and Discussion}

\section{Wheat yield}

Data on wheat yield (Table 2) indicated that the FLDs given a good impact on the farming community of Bikaner district as they were motivated by the new agricultural technologies adopted in the demonstrations. On an average, wheat yield under front line demonstrations recorded was $3984 \mathrm{~kg} / \mathrm{ha}$ which was higher by $17.21 \%$ over farmers' practice $(3395 \mathrm{~kg} / \mathrm{ha})$. Among wheat varieties, highest yield was noticed at $4615 \mathrm{~kg} / \mathrm{ha}$ by Raj 4037 during the year 2013-14. Similarly, highest yield under farmers' practice was also recorded by the same variety (Raj 4037) which was $3850 \mathrm{~kg} / \mathrm{ha}$. Overall, the yield under demonstration plots exceeded that of farmers' plots in all the demonstrated plots in real farm situation. Such enhancement in yield might be attributed to adoption of newly released high yielding varieties, improved agro-techniques in demonstrations which resulted in higher grain yield than that in the farmers' practices (Verma et al., 2016). However, the variations in the yield were observed over the years and it attributed the climatic conditions and incidence of disease and pests. These results are in close conformity with the research findings reported by Sharma et al., (2016).

\section{Technology gap}

The technology gap or technology yield gap is the difference or gap between the demonstrations yield and potential yield. The technological gaps in adoption of wheat production technologies under demonstrations and local farmers' practices were measured.

The major technological gaps were observed regarding improved varieties, seed rate, seed treatment, time of sowing, fertilizers, weed management, irrigation management, plant protection and frost management. The technology gap ranges from 1350-2730 kg/ha with an average technology gap recorded at $2124 \mathrm{~kg} / \mathrm{ha}$ (Table 3) during all the years of study. Moreover, the minimum technology yield gap of $1215 \mathrm{~kg} / \mathrm{ha}$ was recorded during the year 2013-14 under the variety Raj 4037 and maximum of $2730 \mathrm{~kg} / \mathrm{ha}$ during the year 2016-17 using the variety Raj 4120. Under the present investigation, on an average, the technology yield gap of $2124 \mathrm{~kg} /$ has hows the potential of improved varieties and recommended package of practices. The observed technology yield gap ascribed to variations in soil fertility, salinity and erratic rainfall and other vagaries of weather conditions in the region. Therefore, to narrow down the gap between the yields of different varieties, location specific recommendation appears to be necessary (Singh et al., 2019). 


\section{Extension gap}

The extension yield gap is the difference or gap between the yield under demonstration plot and farmers' practice (control) plot. The extension yield gap ranges from 400-800 $\mathrm{kg} / \mathrm{ha}$ with an average extension yield gap of $589 \mathrm{~kg} / \mathrm{ha}$ (Table 3) during all the years of demonstrations. So as to enhance the farmers' income, there is need to decrease this wider extension gap through implementation of latest agro-techniques. This wider extension gap accentuated the need to educate the farmers through various means for the adoption of improved agricultural production technologies to bridge this trend of wide extension gap. More and more use of latest production technologies with high yielding varieties will subsequently change this alarming trend of galloping extension gap. These results are in close conformity with that of reported by Verma et al., (2014) and Sharma et al., (2016).

\section{Technology index}

The technology index indicates (Table 3) the feasibility of the evolved technology at the farmer's fields. The lower the value of technology index more is the feasibility of the technology. Under the experimentation, technology index value ranged from $22.18 \%$ to $45.19 \%$ with an average value of $34.49 \%$ over the years. The greatest technology index was observed during 2015-16 when cultivated Raj 4037 (45.19\%) and lowest in the year 2013-14 under the cultivar Raj 4037 $(22.18 \%)$. The variations ascribed to the climatic variability, insect pest incidence and soil fertility vagaries. The results are corroborating with the findings of Verma et al., (2014); Sharma et al., (2016) and Verma et al., (2016).

\section{Economic analysis}

Economics, an imperative parameter to reject or accept the technology was estimated under the study. Different variables like seed, fertilizers, seeding, chemicals, herbicides and pesticides were considered as cash inputs for the FLD demonstrations as well as for farmers' practice. The economics of the improved technology over farmers' practice were calculated using the prevailing market prices of the inputs and outputs during the particular year (Table 4). From the investigation, it was noticed that on an average, gross cost for raising wheat under demonstration was ₹ 28,754 however, under farmers' practice (control) the gross cost was ₹ $26,695 / \mathrm{ha}$. Under the present investigation, front line demonstrations fetched higher net returns to the tune of $₹ 17,563 / \mathrm{ha}$ to ₹ 52,356/ha with the mean of six yeas was ₹ 37,243/ha. However, under farmers' practices the net returns ranged to the tune of ₹ $15,613 \mathrm{ha}^{-1}$ to ₹ $42,064 /$ ha over the years and its average value fetched to ₹ 29,557/ha. On an average, benefit cost ratio under front line demonstrations and farmers' practice was recorded 2.30 and 2.11 , respectively.

The higher benefit cost ratio under demonstrations ascribed due to higher yield obtained under improved technology as compared to farmers' practice. Hence higher benefit cost ratio proved the economic viability of the technology interventions and convinced the farmers' on the utility of improved technologies.

Similarly, average (over the years) additional returns ₹ 7,686/ha and ₹ 2.30/rupee invested fetched under the study. Similar economic benefits owing to adoption of improved technology interventions were also reported by Sharma and Choudhary (2014); Verma et al., (2014) and Sharma et al., (2016).

\section{Farmers' satisfaction}

Evaluation of client satisfaction or customer satisfaction or here under the present 
experimentation farmers' satisfaction is an imperative issue for all types of business organizations as well as farmers' (Baker and Crompton, 2000; Johnson et al., 2001; Yazdanpanah and Feyzabad, 2017). Client satisfaction is an important determinant of customer retention which, in turn, has a very strong effect on profitability and adoption of the technology (Johnson and Fornell, 1991; Bernet et al.,2001). Client satisfaction can also help farmers' acquire new technologies and maximize their profitability. In the present study, Client Satisfaction Index (CSI) revealed that majority of the respondent farmers expressed high $(49.52 \%)$ to the medium $(34.28 \%)$ level of satisfaction regarding the performance of FLDs, whereas, very few $(16.19 \%)$ of respondents expressed lower level of satisfaction (Table 5). The higher to medium level of satisfaction with respect to performance of demonstrated technology indicate stronger conviction, physical and mental involvement of in the front line demonstrations which in turn would lead to higher adoption (Bernet et al., 2001; Kumaran and Vijayaragavan, 2005; Zhenlin and Xiaona, 2013).

Table.1 Intervention points of low yield of wheat and their recommended potential solutions

\begin{tabular}{|c|c|c|c|}
\hline S.No. & Interventions & Demonstration & Farmers' practice \\
\hline 1. & Varieties & Raj 4037, Raj 4079 and Raj 4120 & Raj 3077 and Raj3765 \\
\hline 2. & Seed rate $(\mathrm{kg} / \mathrm{ha})$ & 100 & 150 \\
\hline 3. & Seed treatment & $\begin{array}{l}\text { Mancozeb50WP, Carbendazim50WP@ } \\
2 \mathrm{~g} / \mathrm{kg} \text { seed }\end{array}$ & Without seed treatment \\
\hline 4. & Time of sowing & $1^{\text {st }}$ to $4^{\text {th }}$ week of November & November 15 to December 15 \\
\hline 5. & Fertilizers & $\begin{array}{l}\text { 120:40:20 (N:P:K) kg/ha and Zinc } \\
\text { sulphate }(33 \%) 15 \mathrm{~kg} / \mathrm{ha}\end{array}$ & 150:60: 00 (N:P:K) kg/ha \\
\hline 6. & Hoeing and weeding & $\begin{array}{l}\text { 2,4-D } 38 \text { EC@ } 500 \mathrm{~g} / \mathrm{ha} \text { (Ester) at 30-35 } \\
\text { DAS for broad leaf weeds } \\
\text { (BLW),Sulfosulfuron75 WG@ } 25 \mathrm{~g} / \mathrm{ha} \\
\text { after first irrigation for grassy weeds }\end{array}$ & Hoeing after $1^{\text {st }}$ irrigation \\
\hline 7. & $\begin{array}{l}\text { Irrigation } \\
\text { management }\end{array}$ & $\begin{array}{l}\text { Six Irrigation (Due to light } \\
\text { soils): } 1^{\text {st }} \text { Irrigation: At CRI stage (20-25 } \\
\text { DAS) } \\
2^{\text {nd }} \text { Irrigation: At tillering stage ( } 40-45 \\
\text { DAS) } \\
3^{\text {rd }} \text { Irrigation: At node formation stage } \\
\text { (60-65 DAS) } \\
4^{\text {th }} \text { Irrigation: At flowering stage ( } 75-80 \\
\text { DAS) } \\
5^{\text {th }} \text { Irrigation: At milk formation stage } \\
\text { (90-95 DAS) } \\
6^{\text {th }} \text { Irrigation: At grain filling stage (105- } \\
110 \text { DAS) }\end{array}$ & $\begin{array}{l}\text { Frequent Irrigation } \\
\text { not at critical stage }\end{array}$ \\
\hline 8. & Plant protection & $\begin{array}{l}\text { Termite Chlorpyriphos } 20 \text { EC @ } 4.0 \\
\text { liter in standing crop }\end{array}$ & Nil \\
\hline 9. & Frost management & $\begin{array}{l}\text { Spray of sulphuric acid @ } 0.1 \% \text { on } \\
\text { forecasting of frost }\end{array}$ & Nil \\
\hline
\end{tabular}


Table.2 Performances and yield under demonstration and yield analysisof wheat in Bikaner district of Rajasthan

\begin{tabular}{|c|c|c|c|c|c|c|c|c|c|c|c|c|c|}
\hline \multirow[t]{2}{*}{ Year } & \multirow[t]{2}{*}{ Variety } & \multirow{2}{*}{$\begin{array}{c}\text { Number } \\
\text { of } \\
\text { demonst } \\
\text { ration }\end{array}$} & \multirow[t]{2}{*}{$\begin{array}{c}\text { Area } \\
\text { (ha) }\end{array}$} & \multicolumn{2}{|c|}{$\begin{array}{l}\text { Average yield } \\
(\mathrm{kg} / \mathrm{ha})\end{array}$} & \multirow{2}{*}{$\begin{array}{c}\% \\
\text { Increase } \\
\text { in yield } \\
\text { over FP }\end{array}$} & \multirow{2}{*}{$\begin{array}{c}\text { District } \\
\text { average } \\
\text { yield } \\
(\mathbf{k g} / \mathrm{ha})\end{array}$} & \multicolumn{2}{|c|}{$\begin{array}{l}\text { Yield (kg/ha) over } \\
\text { district average }\end{array}$} & \multirow{2}{*}{$\begin{array}{c}\text { State } \\
\text { average } \\
\text { yield } \\
\text { (kg/ha) }\end{array}$} & \multicolumn{2}{|c|}{$\begin{array}{c}\text { Yield (kg/ha) } \\
\text { over State } \\
\text { average }\end{array}$} & \multirow{2}{*}{$\begin{array}{c}\text { State } \\
\text { average } \\
\text { yield } \\
\text { (kg/ha) }\end{array}$} \\
\hline & & & & Demo & FP & & & Demo & FP & & Demo & $\mathbf{F P}$ & \\
\hline 2013-14 & Raj 4037 & 60 & 24.0 & 4615 & 3850 & 19.87 & 2469 & 2146 & 1381 & 3438 & 1177 & 412 & 3146 \\
\hline 2014-15 & Raj 4037 & 62 & 24.8 & 3860 & 3370 & 14.54 & 2014 & 1846 & 1356 & 2961 & 899 & 409 & 2750 \\
\hline 2015-16 & Raj 4037 & 60 & 24.0 & 3250 & 2850 & 14.04 & 2464 & 786 & 386 & 3367 & -117 & -517 & 3034 \\
\hline 2017-18 & Raj 4079 & 5 & 2.0 & 4200 & 3400 & 23.50 & 2506 & 1694 & 894 & 3698 & 502 & -298 & 3368 \\
\hline 2018-19 & Raj 4120 & 40 & 16.0 & 4080 & 3500 & 16.62 & 2640 & 1440 & 860 & 3676 & 404 & -176 & 3507 \\
\hline \multicolumn{2}{|c|}{ Average } & 232 & 92.8 & 3984 & 3395 & 17.21 & - & - & - & - & - & - & - \\
\hline
\end{tabular}

Demo=Demonstration; FP=Farmers' practice

Table.3 Gap analysis of wheat under front line demonstrations and farmers' practice in Bikaner district

\begin{tabular}{|c|c|c|c|c|c|}
\hline Year & Variety & $\begin{array}{c}\text { Technology gap } \\
\text { (kg/ha) }\end{array}$ & $\begin{array}{c}\text { Extension gap } \\
\text { (kg/ha) }\end{array}$ & $\begin{array}{c}\text { Technology Index } \\
\mathbf{( \% )}\end{array}$ & $\begin{array}{c}\text { Potential yield } \\
\text { (kg/ha) }\end{array}$ \\
\hline $\mathbf{2 0 1 3 - 1 4}$ & Raj 4037 & 1315 & 765 & 22.18 & 5930 \\
\hline $\mathbf{2 0 1 4 - 1 5}$ & Raj 4037 & 2070 & 490 & 34.91 & 5930 \\
\hline $\mathbf{2 0 1 5 - 1 6}$ & Raj 4037 & 2680 & 400 & 45.19 & 5930 \\
\hline $\mathbf{2 0 1 6 - 1 7}$ & Raj 4120 & 2730 & 500 & 41.18 & 6630 \\
\hline $\mathbf{2 0 1 7 - 1 8}$ & Raj 4079 & 1400 & 800 & 25.00 & 5600 \\
\hline $\mathbf{2 0 1 8 - 1 9}$ & Raj 4120 & 2550 & 580 & 38.46 & 6630 \\
\hline \multicolumn{2}{|c|}{ Average } & 2124 & 589 & 34.49 & - \\
\hline
\end{tabular}


Table.4 Economics of wheat under demonstration and farmers' practice in Bikaner district

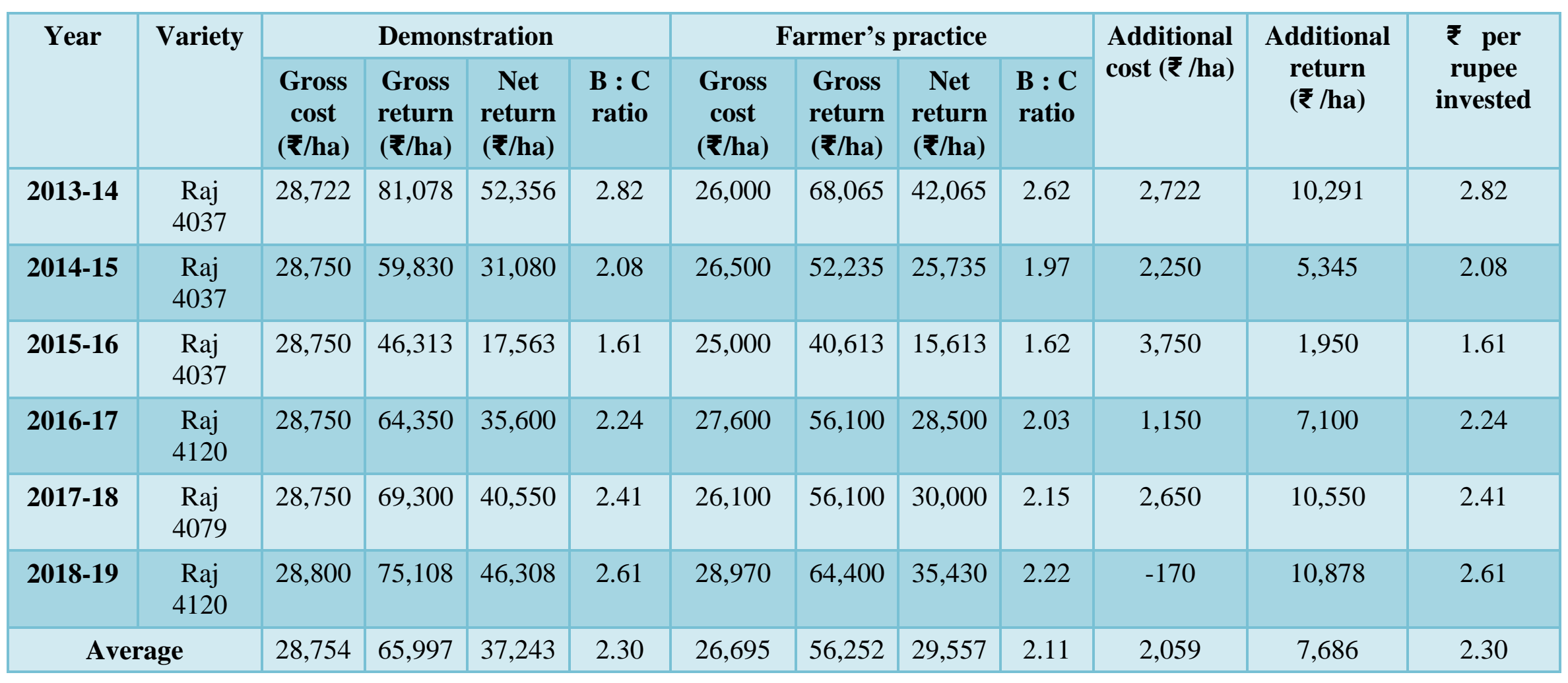

Table 5 Extent of farmer's satisfaction over performance of FLDs ( $\mathrm{n}=105)$

\begin{tabular}{|c|c|c|c|}
\hline S.No. & Satisfaction level & Number & Percentage \\
\hline 1. & High & 52 & 49.52 \\
\hline 2. & Medium & 36 & 34.28 \\
\hline 3. & Low & 17 & 16.19 \\
\hline
\end{tabular}


Table.6 Ranks given by the farmers' for different constraints ( $\mathrm{n}=105)$

\begin{tabular}{|c|l|c|c|}
\hline S.No. & Constraints & Percentage & Ranks \\
\hline $\mathbf{1 .}$ & High temperature at maturity & 74.20 & I \\
\hline $\mathbf{2 .}$ & Lack of high yielding varieties & 71.56 & II \\
\hline $\mathbf{3 .}$ & No irrigation at critical stages & 70.00 & III \\
\hline $\mathbf{4 .}$ & Delay in sowing & 68.45 & IV \\
\hline $\mathbf{5 .}$ & Imbalance use of fertilizers & 66.41 & V \\
\hline $\mathbf{6 .}$ & Termite problem & 55.10 & VI \\
\hline $\mathbf{7 .}$ & Use of high seed rate & 53.76 & VII \\
\hline $\mathbf{8 .}$ & Less attention on weeding & 49.45 & VIII \\
\hline $\mathbf{9 .}$ & No seed treatment & 31.84 & IX \\
\hline $\mathbf{1 0 .}$ & Frost management & 25.66 & X \\
\hline
\end{tabular}

Table.7 Extent of adoption level of the respondents $(\mathrm{n}=105)$ for wheat productiontechnologies

\begin{tabular}{|l|l|c|c|c|c|c|c|}
\hline S.No. & Production technologies & \multicolumn{2}{|c|}{ Before FLDs } & \multicolumn{2}{c|}{ After FLDs } & \multicolumn{2}{c|}{$\begin{array}{c}\text { Increase in } \\
\text { adoption level }\end{array}$} \\
\cline { 3 - 8 } & & Number & Percent & Number & Percent & Number & Percent \\
\hline 1. & Land preparation & 72 & 68.57 & 94 & 89.52 & 22 & 30.56 \\
\hline 2. & Quality seed & 67 & 63.81 & 90 & 85.71 & 23 & 34.33 \\
\hline 3. & Seed treatment & 60 & 57.14 & 91 & 86.67 & 31 & 51.67 \\
\hline 4. & Seed rate and spacing & 56 & 53.33 & 75 & 71.43 & 19 & 33.93 \\
\hline 5. & Sowing time and method & 64 & 60.95 & 88 & 83.81 & 24 & 37.50 \\
\hline 6. & Irrigation at critical stages & 61 & 58.10 & 96 & 91.43 & 35 & 57.38 \\
\hline 7. & Timely weeding & 55 & 52.38 & 81 & 77.14 & 26 & 47.27 \\
\hline 8. & Balanced fertilization & 45 & 42.86 & 77 & 73.33 & 37 & 82.22 \\
\hline 9. & Harvesting & 69 & 65.71 & 85 & 80.95 & 16 & 23.19 \\
\hline 10. & Storage & 70 & 66.67 & 82 & 78.10 & 12 & 17.14 \\
\hline
\end{tabular}

\section{Constraints in wheat production}

Farmer's wheat production problems were documented in this study. Preferential ranking technique was utilized to identify the constraints faced by the respondent farmers in wheat production. The ranking given by the different farmers'are given in Table 6. Perusal of results indicates that effect of heat at maturity $(74.20 \%)$ was given the top most rank followed by lack of high yielding varieties $(71.56 \%)$ and no irrigation at critical stages $(70.00 \%)$. Based on the ranks given by the respondent farmers' for the different constraints revealedthat delay in sowing
(68.45\%), improper use of manures and fertilizers $(66.41 \%)$ and less attention on hoeing and weeding (49.45\%). Other constraints such as use of higher seed rate $(53.76 \%)$, frost management $(25.66 \%)$ were found to reduce wheat production. Other studies (Jatav et al., 2010; Sharma and Choudhary, 2014; Verma et al., 2016) have also reported similar problems in wheat production.

\section{Extent of adoption level of farmers'}

The data regarding adoption of the improved wheat production technologies were also 
recorded under two heads like; adoption before conducting and after conducting frontline demonstrations (Table 7). The results envisage that highest level of adoption was observed for the technology of balanced fertilization $(82.22 \%)$ followed by irrigation at critical stages $(57.38 \%)$, seed treatment $(51.67 \%)$, timely weeding $(47.27 \%)$, sowing time and method (37.50\%), quality seed $(34.33 \%)$, seed rate and spacing (33.93\%), land preparation (30.56\%), harvesting (23.19) and storage (17.14\%). Comparatively, low level of adoption was observed for the technology like seed rate and spacing, as the farmers' are practicing high seed rate with dense planting. The findings of the study also revealed that wheat farmers' had high adoption rate for storage even before (66.67\%) and after (78.10\%) availing trainings and conducting front line demonstration. The reason being greater awareness for storing quality seed for future use. Moreover, greater level of adoption might ascribed to the enhancement in knowledge, skills and confidence level of farmers' through training programmes on different production technologies of wheat crop like; high yielding varieties, optimum seed rate and spacing, seed treatment, soil testing, seed treatment, weeding, plant protection measures, irrigation scheduling, fertilizer application and harvesting has helped farmers to improve the yield of wheat crop (Singh et al., 2007;Sharma and Choudhary, 2014; Singh et al., 2019)

In conclusion the frontline demonstrations conducted on wheat at the farmers' fields substantially enhanced yield, economic returns and adoption of improved production technologies. Moreover, the yield level under FLDs was higher over local practices and therefore, the performance could be further improved by adopting recommended production technologies. Therefore, it is required to disseminate the improved production technologies among the farmers' with effective extension methods like training and demonstrations. Further, the farmers should be encouraged to adopt the improved technologies for higher returns in location specific wheat cultivation. The findings also inferred that the maximum number of the respondents had medium level of knowledge and extent of adoption regarding recommended wheat production technology.

\section{Acknowledgement}

The financial support to meet the expenses towards frontline demonstrations by Department of Agricultural \& Farmers Welfare, Government of India under National Food Security Mission scheme through its nodal agency ICAR-Agricultural Technology Application Research Institute, Jodhpur, Rajasthan is gratefully acknowledged.

\section{References}

Anonymous, 2018. Rajasthan Agricultural Statistics at a Glance, Statistical Cell, Commissionerate of Agriculture, Government of Rajasthan, Jaipur. Available from: http://www.agriculture.rajasthan.gov.in /content/agriculture/en/Agriculture-

Department-dep/agriculturestatistics.html

Anonymous, 2019. Directorate of Economics and Statistics, Department of Agriculture, Cooperation and Farmers Welfare, Ministry of Agriculture and Farmers Welfare, Government of India, New Delhi. Available from: https://eands.dacnet.nic.in/APY_96_To 06.htm

Baker, D. A. and Crompton, J.L. 2000. Quality, satisfaction and behavioural intentions. Annals of Tourism Research27(3): 785-804.

Bernet, T., Ortiz, O., Estrada, R.D., Quiroz, 
R. and Swinton, S.M. 2001. Tailoring agricultural extension to different production contexts: A user-friendly farm-household model to improve decision-making for participatory research. Agricultural Systems69(3): 183-198.

Jatav, H.R., Patel, M.M., Kumar, K.S. and Saxena, A. 2010. Impact ff Front Line Demonstrations on Scientific Temperament of Wheat Growers. Rajasthan Journal of Extension Education 17\&18: 14-16.

Johnson, M.D. and Fornell, C. 1991. A framework for comparing customer satisfaction across individuals and product categories. Journal of Economic Psychologyl2(2): 267-286.

Johnson, M.D., Gustafson, A., Andreassen, T.W., Lervik, L. and Cha, J. 2001. The evolution and future of national customer satisfaction index models. Journal of Economic Psychology22(2): 217-245.

Joshi, A.K., Mishra, B., Chatrath, R., Ortiz Ferrara, G. and Singh, R.P. 2007. Wheat improvement in India: Present status, emerging challenges and future prospects. Euphytica. 157(3): 457-64.

Kumaran, M. and Vijayaragavan, K. 2005. Farmers' satisfaction of agricultural extension services in an irrigation command area. Indian Journal of Extension Education41(3\&4): 8-12.

Nagarajan, S. 1997. Perspectives on wheat demand and research needs. Wheatresearch needs beyond $2000 \mathrm{AD}$. In: Proceedings of International Group Meeting held at DWR, Karnal, India, 12-14 Aug. pp. 14-15.

Samui, S.K., Maitra, S., Roy, D.K., Mondal, A.K. and Saha, D. 2000. Evaluation of front line demonstration on groundnut (Arachis hypogea L.) in Sundarbans. Journal of the Indian Society of Coastal Agricultural Research 18 (2):
180-183.

Sharma, R., and Choudhary, P.C. 2014. Improvement in Wheat Productivity through Frontline Demonstrations. Indian Journal of Extension Education and Rural Development. 22: 36-41.

Sharma, V., Kumar, V., Sharma, S.C and Singh, S. 2016. Productivity enhancement and popularization of improved production technologies in wheat through frontline demonstrations. Journal of Applied and Natural Science 8(1): 423-428.

Singh, D.K., Gautam, U.S. and Singh, R.K. 2007. Study on yield gap and level of demonstrated crop production technology in Sagar district. Indian Research Journal of Extension Education7(2\&3): 94-95.

Singh, S., Kumar, A., Sendhil, R., Singh, R., Singh, M., Chand, R. and Singh, G.P. 2019. Impact of Wheat Frontline Demonstrations in India: A Decade of Experience. Research Bulletin No: 41, ICAR-Indian Institute of Wheat and Barley Research, Karnal. pp 1-102.

Tiwari, B.K., Sharma, A., Sahare, K.V., Tripathi, P. N. and Singh, R.R. 2014. Yield gap analysis of wheat (Triticum aestivum) through front line demonstration under limited irrigation conditions. Plant Archives 14(1): 495498.

Verma, R.K., Dayanand, Rathore, R.S., Mehta, S.M. and Singh, M. 2014. Yield and gap analysis of wheat productivity through frontline demonstrations in Jhunjhunu district of Rajasthan Annals of Agricultural Research New Series 35(1): 79-82.

Verma, A.K., Jeengar, K.L., Ram, J. and Naager, K.C. 2016. Popularization of high yielding varieties of wheat (Triticum aestivum L.) in Jhalawar district of Rajasthan state through Frontline Demonstrations. Journal of 
Wheat Research 8(1): 39-44.

Yazdanpanah, M. and Feyzabad, F.R. 2017. Investigating Iranian farmers' satisfaction with agricultural extension programs using the American customer satisfaction index. Journal of Agricultural \& Food Information 18(2): 123-135.

Zhenlin, W. and Xiaona, W. 2013.
Influencing factors analysis of farmers' satisfaction index to participate in small-scale irrigation and water conservancy management: Based on survey data of Jiangxi province. Agricultural Economics and Management 4: 53-62.

\section{How to cite this article:}

Shivran, R. K., Naval Kishor, Ummed Singh, B. S. Kherawat, Keshav Mehra and Richa Pant. 2020. Productivity, Profitability and Yield Gap Analysis of Wheat (Triticum aestivum L.) under Irrigated Conditions of Rajasthan. Int.J.Curr.Microbiol.App.Sci. 9(07): 1597-1608. doi: https://doi.org/10.20546/ijcmas.2020.907.184 